\title{
Cardioprotective effects of Citrullus lanatus rinds in male wistar rats
}

${ }^{1}$ Akintunde, O. G., ${ }^{1}$ Ajibola, E. S., ${ }^{2}$ Abakpa, S. A. V., 'Oluwo, B. H. and ${ }^{1}$ Olukunle, J. O. ${ }^{1}$ Department of Veterinary Physiology and Pharmacology,

${ }^{2}$ Department of Veterinary Medicine and Surgery, College of Veterinary Medicine, Federal University of Agriculture, Abeokuta Ogun state Nigeria.

Corresponding author: akintunndegrace@yahoo.com; +2348033188439

\begin{abstract}
Water melon, citrullus lanatus is a common edible fruit belongs to the family of cucumber (Cucurbitacea). The outer part of citrullus lanatus known as the rind is always discarded. This study investigated the effects of ethanol extract of citrullus lanatus rinds orally administered on some liver function enzymes, kidney function markers, cardiac risk ratio, and the atherogenic coefficient indices in male wistar rats. Twenty-five male Wistar albino rats were randomly distributed into five groups (I, II, III, IV and V) of five rats each received $0 \mathrm{mg} / \mathrm{kg}, 100 \mathrm{mg} / \mathrm{kg}, 200 \mathrm{mg} / \mathrm{kg}, 400 \mathrm{mg} / \mathrm{kg}$ and $800 \mathrm{mg} / \mathrm{kg}$ of ethanol extract of Citrullus lanatus rinds respectively for 35days. The result showed that the effects of ethanol extract of citrullus lanatus rinds was not significant difference $(p>0.05)$ in serum liver enzymes (Aspartate aminotransferase, Alanine aminotransferase, Alkaline phosphatase) in increasing dose dependent manner when compared with control group. There were no significant differences $(p>0.05)$ in serum levels of urea and creatinine with increasing dose of ethanol extract of Citrullus lanatus rinds in rats when compared with control group. The extract showed significantly higher $(p<0.05)$ values in the serum $H D L$, cholesterol but there were significant reduction $(p<0.05)$ in the serum total cholesterol, triglycerides, $L D L, V L D L$ and non-HDL values in rats at higher doses of the extract when compared with control group. While it was observed that the cardiac risk ratio, the atherogenic coefficient and indices decreased significantly $(p<0.05)$ in rats at increasing doses of ethanol extract of Citrullus lanatus rinds when compared with control group. This may suggest a likely cardioprotective effects of ethanol extract of Citrullus lanatus rinds in increasing dose dependent manner in rats when compared with control group. In conclusion, it can be inferred that Citrullus lanatus rinds can be consumed by animals without detrimental effect.
\end{abstract}

Keywords: Citrullus lanatus rinds, cardio-protective, rats.

\section{Introduction}

Watermelon, Citrullus lanatus belongs to the family of cucumber (Cucurbitacea). It is large, oval, round or oblong in shape. It is a tropical fruit grown in almost all part of Africa and South East Asia (Kolawole et al., 2014). The Citrullus lanatus (C. lanatus) is a popular species with high water content (as high as $92 \%$ of the total weight (Mabberley, 1987). C. lanatus is traditionally used for centuries in the treatment of various health aliments. It is an important medicinal plant in the Cucurbitaceae. C. lanatus is an important horticultural crop, is usually sweet and juicy fruit found in warm climates all over the world (Gill et al., 2011). It has been reported that elevated plasma level of LDL cholesterol is a risk factor for cardiovascular disease (Ademuyiwa et al., 2005; Lichtennstein et al., 2006) and often accompanies hypertension (Shepherd 1998; Zicha et al., 1999). Conversely, reductions in plasma LDL cholesterol have been 


\section{Cardioprotective effects of Citrullus lanatus rinds in male wistar rats}

considered to reduce risk of coronary heart disease (Rang et al., 2005; Shen 2007). Many studies have shown that non-HDL cholesterol is a better marker of cardiovascular disease risk than LDL cholesterol, (Liu et al., 2005; Pischon et al., 2005). Therefore, the significantly lower plasma non- HDL cholesterol observed in the treated diabetic groups is another indicator of the ability of the extract to reduce cardiovascular risk (Brunzell et al., 2008). The kidney is highly susceptible to toxicants because a high volume of blood flows through it and it filters large amounts of toxins which can concentrate in the kidney tubules (Emily, 2007). Nephrotoxicity can result in systemic toxicity causing decreased ability to excrete body wastes, inability to maintain body fluid, electrolyte imbalance and decreased synthesis of essential hormones (Emily, 2007). Atherogenic indices are powerful indicators of heart disease, the higher the value, the higher the risk of developing cardiovascular disease and vice versa, (Dobiásová 2004; Martirosyan et al., 2007). Low atherogenic indices are indications against protection of coronary heart disease, (Brown and Hebert 1997; Usoro et al., 2006; Krauss et al., 2007). There is dearth of information on effects of Citrullus lanatus rinds on heart and kidney in man and animal. This study investigated the effects of Citrullus lanatus rinds on serum lipid profile and some biochemical changes affecting the liver and heart in male wistar rats.

\section{Material and methods \\ Preparation of ethanol extracts of citrullus lanatus rinds}

Water melon (Citrullus lanatus) fruit was purchased from Hausa market, Eleweran, Abeokuta. The C. lanatus fruit was washed under running tap water and carefully sliced to pieces knife. The rind of the $C$. lanatus fruit (CLR) was carefully removed from the whole fruit, chopped into smaller pieces and sundried. It was later pulverized using an electric blender (Euro-premium mixer grinder $^{\mathrm{R}}$ ). $1000 \mathrm{~g}$ of pulverished Citrullus lanatus rinds was extracted by percolation at room temperature in $70 \%$ alcohol for 48hours. The Citrullus lanatus rinds was concentrated under reduced pressure (temperature of $50^{\circ} \mathrm{c}$ ) and finally defatted with n-hexane. The extract was evaporated to dryness. The ethanol extract of Citrullus lanatus rinds was stored at $4^{\circ} \mathrm{C}$ until use.

\section{Experimental design and administration of extract}

Twenty-five healthy Wistar albino rats weighing 175-190g were used for this study. The rats were maintained on $12 \mathrm{~h}$ light and dark cycle in the experimental unit. The rats were fed with pelletized commercial rat feed (Vital feed ${ }^{\mathrm{R}}$ ). They had access to feed and water ad libitum. The rats were acclimatized for 2 weeks before commencement of the experiment. The rats were randomly distributed into five groups of five rats each (group I -V). An acute toxicity test was done with this extract, using the liver function enzymes as the parameters of study. It revealed that the extract was not toxic up to $2000 \mathrm{mg} / \mathrm{kg}$ body weight. This was used as a guide in dose administration. Group I served as control and received $10 \mathrm{~mL} / \mathrm{kg}$ bodyweight of normal saline as the vehicle once daily for 35 days $(0 \mathrm{mg} / \mathrm{kg}$ of ethanol extract of Citrullus lanatus rinds). Groups II, III, IV and $\mathrm{V}$ received 100, 200, 400 and 800 $\mathrm{mg} / \mathrm{kg}$ of ethanol extract of Citrullus lanatus rinds, respectively. The ethanol extract of the Citrullus lanatus rinds was orally administered once daily using oral gastric tube for 35 days.

Blood collection and biochemical analysis

The rats were anaesthetized and the blood 


\section{Akintunde, Ajibola, Abakpa, Oluwo and Olukunle}

was collected by retro-orbital venous plexus puncture for serum biochemical studies. The blood in plain bottle was centrifuged at 3,500 r.p.m for $10 \mathrm{mins}$ and serum was separated with Pasteur pipette for the analysis of alanine transaminase, aspartate transaminase and alkaline phosphatase. The activities of alanine and aspartate transaminases were respectively measured by monitoring at $546 \mathrm{~nm}$, the concentrations of pyruvate and oxaloacetate hydrazones formed with 2,4dinitrophenylhydrazine. The activity of alkaline phosphatase was determined by monitoring the degradation of $\mathrm{p}$ nitrophenyl-phosphate to p-nitrophenol, at $405 \mathrm{~nm}$. Serum urea concentration was determined using Randox test kits (Randox Laboratories, Crumlin, England, UK). The wavelength for the determination of urea was $546 \mathrm{~nm}$ using Randox test kits.

The following lipid profiles and cardiac indices were determined according to Friedewald and Friedrickson (1972):

$[$ VLDL cholesterol $]=[\underline{\text { Triglycerides }]}$

$$
2.2
$$

$[$ L D L $]=[$ Total cholesterol $]-[$ HDL cholesterol $]-[$ Triglyceride]

$$
2.2
$$

Cardiac Risk Ratio $(\mathrm{CRR})=[$ Total Choles te r o $]$

$$
\text { [HDL] }
$$

Atherogenic Coefficient $(\mathrm{AC})=[$ T o t a lcholester

ol]-[HDLcholesterol]

[HDL]

Atherogenic Index of Serum (AIS) $=\log [\mathrm{T} \mathrm{rigly} \mathrm{cer}$ ide]

cholesterol]

[HDL

The serum non-HDL cholesterol concentration was determined as reported by Brunzell et al. (2008):

[Non-HDL cholesterol] = [Total cholesterol]-[HDL cholesterol]

\section{Statistical analysis}

Data obtained were analyzed using analysis of variance while means were separated using Duncan multiple range test.

\section{Results}

Effects of ethanol extract of Citrullus lanatus rinds on serum hepato-specific markers in wistar rats. This study showed that there were no significant differences $(p>0.05)$ in the values of serum aspartate aminotransferase (AST), alanine aminotransferase (ALT), alkaline phosphatase (ALP) and globulin in increasing doses from $100 \mathrm{mg} / \mathrm{kg}$ to 800 $\mathrm{mg} / \mathrm{kg}$ ethanol extract of Citrullus lanatus rinds in wistar rats when compared with control $(0 \mathrm{mg} / \mathrm{kg})$ ethanol extract of Citrullus lanatus rinds in wistar rats (Table 1).

\begin{tabular}{|c|c|c|c|}
\hline Groups & $\begin{array}{l}\text { Aspartate } \\
\text { transaminase, AST } \\
(\mathrm{U} / \mathrm{L})\end{array}$ & $\begin{array}{l}\text { Alanine transaminase, } \\
\text { ALT } \\
(\mathrm{U} / \mathrm{L})\end{array}$ & $\begin{array}{l}\text { Alkaline } \\
\text { Phosphatase, ALP } \\
\text { (U/L) }\end{array}$ \\
\hline $\mathrm{A},(0 \mathrm{mg} / \mathrm{kg})$ & $47.00 \pm 1.58$ & $13.80 \pm 1.30$ & $51.40 \pm 7.40$ \\
\hline $\mathrm{B}(100 \mathrm{mg} / \mathrm{kg})$ & $49.20 \pm 4.09$ & $17.00 \pm 1.58$ & $59.20 \pm 3.77$ \\
\hline $\mathrm{C}(200 \mathrm{mg} / \mathrm{kg})$ & $50.00 \pm 5.57$ & $14.20 \pm 1.30$ & $59.00 \pm 5.52$ \\
\hline $\mathrm{D}(400 \mathrm{mg} / \mathrm{kg})$ & $50.80 \pm 5.36$ & $17.00 \pm 1.58$ & $60.00 \pm 7.91$ \\
\hline $\mathrm{E}(800 \mathrm{mg} / \mathrm{kg})$ & $52.20 \pm 4.97$ & $16.20 \pm 1.30$ & $57.00 \pm 4.69$ \\
\hline
\end{tabular}

Table 1: Effects of ethanol extract of Citrullus lanatus rinds on serum hepato-specific markers in wistar rats

Effects of ethanol extract of Citrullus lanatus rinds on serum lipid profile in Wistar rats.

There were significant reductions $(\mathrm{p}<0.05)$ in the values of serum total cholesterol, triglycerides, creatinine, urea, sodium, low density lipoprotein, low density lipoprotein and non- high density lipoprotein in 


\section{Cardioprotective effects of Citrullus lanatus rinds in male wistar rats}

increasing doses with administration of $100 \mathrm{mg} / \mathrm{kg}$ to $800 \mathrm{mg} / \mathrm{kg}$ ethanol extract of Citrullus lanatus rinds in male wistar rats when compared with control $(0 \mathrm{mg} / \mathrm{kg})$ ethanol extract of Citrullus lanatus rinds in wistar rats. But there were significant $(p<0.05)$ increase in serum high density lipoprotein in increasing dose dependent manner from $100 \mathrm{mg} / \mathrm{kg}$ to 800 of Citrullus lanatus rinds in wistar rats when compared with control $(0 \mathrm{mg} / \mathrm{kg})$ of Citrullus lanatus rinds in Wister rats (Table 2).

\begin{tabular}{|c|c|c|c|c|c|c|c|c|}
\hline Group & $\begin{array}{l}\text { Total Cholesterol } \\
(\mathrm{mg} / \mathrm{dl})\end{array}$ & $\begin{array}{l}\mathrm{HDL} \\
(\mathrm{mg} / \mathrm{dl})\end{array}$ & $\begin{array}{l}\text { Triglycerides } \\
(\mathrm{mg} / \mathrm{dl})\end{array}$ & $\begin{array}{l}\text { Creatinine } \\
(\mathrm{mg} / \mathrm{dl})\end{array}$ & $\begin{array}{l}\text { Urea } \\
(\mathrm{mg} / \mathrm{dl})\end{array}$ & $\begin{array}{l}\text { VLDL } \\
(\mathrm{mg} / \mathrm{dl})\end{array}$ & $\begin{array}{l}\mathrm{LDL} \\
(\mathrm{mg} / \mathrm{dl})\end{array}$ & $\begin{array}{l}\text { Non-HDL } \\
(\mathrm{mg} / \mathrm{dl})\end{array}$ \\
\hline $\mathrm{A},(0 \mathrm{mg} / \mathrm{kg})$ & $105.57 \pm 1.62$ & $19.37 \pm 0.82$ & $78.17 \pm 9.32$ & $1.06 \pm 0.00$ & $90.00 \pm 30.8$ & $35.53 \pm 4.24$ & $50.67 \pm 3.35$ & $86.20 \pm 1.88$ \\
\hline $\mathrm{B}(100 \mathrm{mg} / \mathrm{kg})$ & $97.91 \pm 6.35$ & $26.31 \pm 2.33$ & $66.91 \pm 2.74$ & $0.90 \pm 0.02$ & $50.11 \pm 6.89^{b}$ & $30.42 \pm 1.25^{\mathrm{b}}$ & $41.19 \pm 7.17$ & $71.60 \pm 7.74$ \\
\hline $\mathrm{C}(200 \mathrm{mg} / \mathrm{kg})$ & $87.34 \pm 7.39$ & $27.30 \pm 2.78$ & $60.93 \pm 2.30$ & $0.80 \pm 0.12^{\mathrm{b}}$ & $38.48 \pm 10.17$ & $27.69 \pm 1.05$ & $32.35 \pm 7.90$ & $60.04 \pm 7.54$ \\
\hline $\mathrm{D}(400 \mathrm{mg} / \mathrm{kg})$ & $73.11 \pm 7.44$ & $32.66 \pm 0.71$ & $53.52 \pm 3.78^{\mathrm{b}}$ & $0.66 \pm 0.06^{\mathrm{ab}}$ & $26.35 \pm 3.46$ & $24.32 \pm 1.72$ & $16.12 \pm 8.96$ & $40.45 \pm 8.07$ \\
\hline $\mathrm{E}(800 \mathrm{mg} / \mathrm{kg})$ & $43.84 \pm 15.38^{\mathrm{a}}$ & $37.28 \pm 1.93^{\mathrm{a}}$ & $39.63 \pm 15.71^{\mathrm{ab}}$ & $0.48 \pm 0.08^{\mathrm{ab}}$ & $8.87 \pm 4.37^{\mathrm{ab}}$ & $18.01 \pm 7.14^{\mathrm{ab}}$ & $-11.45 \pm 16.64^{\mathrm{a}}$ & $6.56 \pm 14.63$ \\
\hline
\end{tabular}

Effects of ethanol extract of Citrullus lanatus rinds on serum cardio-specific markers in Wister rats.

This study showed that there was statistically significant $(\mathrm{p}<0.05)$ decrease in serum cardio-specific markers like the atherogenic coefficient, atherogenic indices and the cardiac risk ratio values in increasing dose dependent manner from $100 \mathrm{mg} / \mathrm{kg}$ to 800 of Citrullus lanatus rinds in Wister rats when compared with control,(Table 3).

Table 3: Effects of ethanol extract of Citrullus lanatus rinds on serum cardio-specific markers in wistar rats

\begin{tabular}{llll}
\hline Group & $\begin{array}{l}\text { Atherogenic } \\
\text { Coeficient }\end{array}$ & $\begin{array}{l}\text { Cardiac risk ratio } \\
\text { CRR }\end{array}$ & $\begin{array}{l}\text { Atherogenic Index of serum } \\
\text { (AIS) }\end{array}$ \\
\hline $\mathrm{A},(0 \mathrm{mg} / \mathrm{kg})$ & $104.57 \pm 1.62$ & $5.46 \pm 0.25$ & $0.10 \pm 0.00$ \\
$\mathrm{~B}(100 \mathrm{mg} / \mathrm{kg})$ & $96.91 \pm 6.35$ & $3.75 \pm 0.50$ & $0.07 \pm 0.01$ \\
$\mathrm{C}(200 \mathrm{mg} / \mathrm{kg})$ & $86.34 \pm 7.32$ & $3.22 \pm 0.40$ & $0.07 \pm 0.01$ \\
$\mathrm{D}(400 \mathrm{mg} / \mathrm{kg})$ & $72.11 \pm 7.44$ & $2.24 \pm 0.27$ & $0.05 \pm 0.00^{\mathrm{a}}$ \\
$\mathrm{E}(800 \mathrm{mg} / \mathrm{kg})$ & $42.84 \pm 15.38$ & $1.17 \pm 0.41^{\mathrm{a}}$ & $0.04 \pm 0.01$ \\
\hline
\end{tabular}

Mean $\pm \mathrm{SD} n=5 ; \quad$ a is $\mathrm{P}>0.05$ value significant when compared with control

while $\mathrm{b}$ is $\mathrm{P}>0.05$ value significant when compared the groups across the column.

\section{Discussion}

When liver cell membrane is damaged the liver functions is impaired a variety of enzymes ( alanine transaminase, aspartate transaminase and alkaline phosphatase) normally located in the cytosol are released into the blood circulation (Mitra et al., 1998) this will now increase there values in the serum. But in this study with administration of ethanol extract of Citrullus lanatus rinds there was no significant differences in the serum values of all the liver function enzymes (Alanine transaminase, Aspartate transaminase and Alkaline phosphatase) indicating that there is protection to liver cell membrane which have prevented the leakage of the cellular enzymes into the blood circulation. High levels of serum triglyceride may be both an independent and synergistic risk factor for cardiovascular diseases (Dobiásová 2004; Martirosyan et al., 2007; Mcbride, 2007). This study showed significant decrease in the serum triglyceride in increasing dose dependent manner, which is an indication of cardio-protective effects of ethanol extract of Citrullus lanatus rinds in the treated rats when compared with the control group (Table 2). This effect may have been facilitated by vitamin $\mathrm{C}$ and flavonoid 


\section{Akintunde, Ajibola, Abakpa, Oluwo and Olukunle}

present in the extract since vitamin C (Ikewuchi et al., 2009) and flavonoids (Ikewuchi et al., 2010) are known to decrease triglyceride level in the blood circulation.

The administration of ethanol extract of Citrullus lanatus rinds caused significant increase in serum HDL cholesterol levels in increasing dose dependent manner (Table $2)$. This is in line with the reports of Rang et al. (2005) and Krauss et al. (2006) that increase in HDL cholesterol concentration in blood will reduce cardiovascular risk in the body.

High level of LDL cholesterol is a risk factor for cardiovascular disease (Ademuyiwa et.al., 2005) this can often accompanies hypertension (Zicha et al., 1999). In contrast reduction in plasma LDL cholesterol level have been shown to reduce risk of coronary heart disease (Shen, 2004 and Rang et al., 2005). In this study a significant reduction in serum LDL cholesterol levels was observed in the rats that received the extract in increasing dose dependent manner. This indicates that the extract likely has cardio-protective effect.

Elevated levels of plasma VLDL cholesterol is a risk factor for cardiovascular disease Ademuyiwa et al. (2005) and Lichtennstein et al. (2006). It was however, observed in this study that there was significant decrease in serum VLDL cholesterol level when the extract was administered to the rats in increasing dose dependent manner this indicates that the extract has cardio-protective potential (Brunzell et al.,2008).

Many studies have shown that non-HDL cholesterol is a better predictor of cardiovascular disease risk than is LDL cholesterol ( Brunzell et al., 2008; Liu et al., 2005b and Pischon et al., 2005). Therefore, the significant reduction in the serum non HDL cholesterol observed in the rats that received ethanol extract at increasing dose dependent manner indicates that the extract has cardioprotective potential.

Atherogenic indices are powerful indicators of the risk of heart disease the higher the value, the higher the risk of developing cardiovascular disease and vice versa ( Dobiásová 2004; Martirosyan et al., 2007; Brehm et. al., 2004 and Usoro et al., 2006) while low atherogenic indices are protective against coronary heart disease (Usoro et al., 2006). This again high lights the ability of ethanol extract of Citrullus lanatus rinds to protect against cardiovascular complications as it exhibited low atherogenic values in increasing dose dependent manner in this study (Table 3). Elevated serum levels of urea and creatinine are significant markers of renal dysfunction (El-Demerdash et al., 2005). It was observed in this study that there was significant reduction in serum levels of urea and creatinine when ethanol extract of Citrullus lanatus rinds was administered to the rats in increasing dose dependent manner (Table 3). This indicates that ethanol extract of Citrullus lanatus rinds provides protection to the renal functions of the rats in this study.

\section{Conclusion}

This study demonstrated positive effects of Citrullus lanatus rinds on serum lipid profile and it is cardio-protective effects in male wistar rats. This study had shown that Citrullus lanatus rinds can be consumed by animals without any detrimental effect. Further work is still on going in our laboratory to determine the active ingredients and the likely mechanism of action of this extract on animals.

\section{References}

Ademuyiwa, O., Ugbaja, R. N., Idumebor, F. and Adebawo, $O$. 
Cardioprotective effects of Citrullus lanatus rinds in male wistar rats

2005. Plasma lipid profiles and risk of cardiovascular disease in occupational lead exposure in Abeokuta, Nigeria. Lipids Health Disease 4: 19.

Brunzell, J. D., Davidson, M., Furberg, C. D., Goldberg, R. D., Howard, B. V. and Stein, J. H. 2008. Lipoprotein management in patients with cardiometabolic risk: consensus conference report from the American Diabetes Association and the American College of Cardiology. Foundation. Journal of American College of Cardiology; 51:1512-24.

Brehm, A... Pfeiler, G., Pacini, G, Vierhapper, H. and Roden, $M$. 2004. Relationship between serum lipoprotein ratios and insulin resistance in obesity. Clinical Chemistry. 50(12): 2316-2322.

Crook, M. A. 2006 Clinical chemistry and metabolic medicine, 7th edn. London: Holder Arnold.

Dobiásová, M. 2004. Atherogenic index of plasma [log(triglyceride/ HDLCholesterol)]: theoretical and practical implications. Clinical Chemistry; 50: 1113-1115.

Dubey, G. P., Agrawal, A. and Dixit, S. P. 1994. Effect of Liv-52 on different biochemical parameters in alcoholic cirrhosis, Antiseptic.91, 205-208.

Emily, M. 2007. Toxicity In Encyclopedia of Earth. Eds. Cutler Journal. Cleveland, Washington D.C.

El-Demerdash, F. M., Yousef, M. I. and Abou El-Naga, N. I. 2005. Biochemical study on the hypoglycemic effects of onion and garlic in alloxan-induced diabetic rats. Food Chemistry Toxicology. 43:57-63.
Friedewald, W. T, Levy, R. I. and Friedrickson, D. S. 1972. Estimation of the concentration of low-density lipoprotein cholesterol in plasma without use of the preparative ultracentrifuge. Clinical Chemistry. 18(6): 499502.

Ikewuchi, C. C. and Ikewuchi, J. C. 2009. Amino acid, mineral, and vitamin composition of Sansevieria liberica Gérôme and Labroy. Pacific Journal of Science Technology. 10(1): 477-482.

Ikewuchi, C. C., Ikewuchi, C. J., Ayalogu, O. E. and Onyeike, N. E. 2010. Proximate and phytochemical profile of Sansevieria liberica Gérôme and Labroy. Journal of Applied Science Environmental Management. 14(2): 103-106.

Middleton, E. J., Kandaswami, C. and Theoharides, T. C. 2000. The effects of plant flavonoids on mammalian cells. Implications for inflammation, heart disease and cancer. Pharmacology Revelation. 52(4): 673-751.

Mitra, S. K., Venkataranganna, M. V., S u n d a r a m, R . a n d Gopumadhavan, S. 1998. Protective effect of HD-03, a herbal formulation, against various hepatotoxic agents in rats. Journal of Ethnopharmacology 63.181-186.

Krauss, R. M., Blanche, P. J., Rawlings, R. S., Fernstrom, H. S. and Williams, P. T 2006. Separate effects of reduced carbohydrate intake and weight loss on atherogenic dyslipidemia. American Journal of Clinical Nutrition. 83(6): 1025-1031. 
Kolawole, T. A., Dapper, D. V., Ojeka, S. O. 2014. Ameliorative effects of the methanolic extract of the rind of Citrullus lanatus on lead acetate induced toxicity on semen parameters and reproductive hormones of male albino wistar rats. European Journal of Medicinal Plants. 4(9): 1125-1137.

Lichtennstein, A. H., Appel, L. J., Brands, M., Carnethon, M., Daniels, S. and Franklin, B. 2006. D i e $\mathrm{t}$ a $\mathrm{nd} 1 \mathrm{ifest}$ y $1 \mathrm{e}$ recommendations revision 2006. A Scientific Statement from the American Heart Association Nutrition Committee. Circulation 114(1): 82-96.

Liu, J., Sempos, C., Donahue, R., Dorn, J., Trevisan. M. and Grundy, S. M. 2005. Joint distribution of nonHDL and LDL cholesterol and coronary heart disease risk prediction among individuals with and without diabetes. Diabetes Care. 28(8): 1916-1921.

Mabberley, D. I. 1987. The plant book. Cambridge: Cambridge University Press, New York.

Martirosyan, D. M., Miroshnichenko, L. A., Kulokawa, S. N., Pogojeva, A. V., Zoloedov, V. I. 2007. Amaranth oil application for heart disease and hypertension. Lipids Health Dis. 6:1.

McBride, P. E. 2007. Triglycerides and risk for coronary heart disease. Journal of American Medical Association . 298: 336-338.

Middleton, E. J., Kandaswami, C. and Theoharides, T. C. 2000. The effects of plant flavonoids on mammalian cells. Implications for inflammation, heart disease and cancer. Pharmacology Revelation. 52(4): 673-751.
Mitra, S. K., Venkataranganna, M. V., S u n d a r a m, R. a n d Gopumadhavan, S. 1998 . Protective effect of HD-03, a herbal formulation, against various hepatotoxic agents in rats. Journal of Ethnopharmacology 63.181186.

Parekh, J. and Chanda, S. V. 2007. In vitro antimicrobial activity and phytochemical analysis of some Indian medicinal plants. Turkey Journal of Biology.31:53-58.

Pischon, T., Girman, C. J., Sacks, F. M., Rifai, N., Stampfer, M. J., Rimm, E. B. 2005. Non-high density lipoprotein cholesterol and apolipoprotein B in the prediction of coronary heart disease in men. Circulation. 112(22): 3375-3383.

Rang, H. P., Dale, M. M., Ritter, J. M. and Moore, P. K. 2005. Pharmacology, $5^{\text {th }}$ edn. India: Elsevier.

Shen, G. X. 2007. Lipid disorders in diabetes mellitus and current $\mathrm{m}$ a $\mathrm{n}$ a g e m e n t. Curre n t Pharmaceutical Analysis. 3: 17-24.

Shepherd, J. 1998. Identifying patients at risk for coronary heart disease: Treatment implications. European Heart Journal. 19: 1776-1783.

Usoro, C. A. O., Adikwuru, C. C., Usoro, I. N. and Nsonwu, A. C. 2006. Lipid profile of postmenopausal women in Calabar, Nigeria. Pakistan Journal of Nutrition. 5(1): 79-82.

Zicha, J., Kunes, J. and Devynck, M. A. 1999. Abnormalities of membrane function and lipid metabolism in hypertension: a review. American Journal of Hypertension. 12: 315331.

Received $13^{\text {th }}$ December, 2016 Accepted: $4^{\text {th }}$ March, 2017 